Cahiers « Mondes anciens »

\title{
The Letter as Object. The Written Word between Reification and Hermeneutics in Rabbinic Judaism
}

\section{Madalina Vârtejanu-Joubert}

\section{(2) OpenEdition}

\section{Journals}

\section{Édition électronique}

URL : http://journals.openedition.org/mondesanciens/129

DOI : 10.4000/mondesanciens. 129

ISSN : 2107-0199

\section{Éditeur}

UMR 8210 Anthropologie et Histoire des Mondes Antiques

\section{Référence électronique}

Madalina Vârtejanu-Joubert, «The Letter as Object. The Written Word between Reification and Hermeneutics in Rabbinic Judaism », Cahiers « Mondes anciens » [En ligne], 1 | 2010, mis en ligne le 20 janvier 2010, consulté le 01 mai 2019. URL : http://journals.openedition.org/mondesanciens/129; DOI : 10.4000/mondesanciens.129

Ce document a été généré automatiquement le 1 mai 2019.

\section{(i) () $\Theta$}

Les Cahiers «Mondes Anciens » sont mis à disposition selon les termes de la licence Creative Commons Attribution - Pas d'Utilisation Commerciale - Pas de Modification 4.0 International. 


\title{
The Letter as Object. The Written Word between Reification and Hermeneutics in Rabbinic Judaism ${ }^{1}$
}

\author{
Madalina Vârtejanu-Joubert
}

\section{Introduction}

1 Writing is usually associated with the oral and is studied in light of the cognitive gap coined and theorized by Jack Goody in a theory which has determined the emergence of "literacy studies". My approach for the present paper is not to confront "the written" and "the oral" but "writing" and "ritual". In the case of Judaism, "agency" has never been absent from either religion or historiography: thus, my object here is not that of rehabilitating this notion within Judaism. On the contrary, what I find of particular interest is the possibility to test the relations between "the written", the act of "writing" and "the ritual". I resume here the distinction between "the written" and the act of "writing" that was made by the program's designers, in which the latter term is understood as "the layout itself as seized in its execution during a ritual operation". To put it differently, the notion of "ritual" is already contained within that of "writing" and the fertile tension to be pursued in one's analysis is that between "content" and "form", between "the written meaning" and the material aspects which condition it. Therefore, my attempt is to answer the question launched by the "Avant-propos": "the pragmatic contexts within which the authority of writing is established". This authority is double in the case of Judaism as what is "written" and, starting with a particular moment in history, as the act of "writing". Starting with the Second Temple, the Torah is sacred as "word" and "scroll" at the same time as it is sacred by means of its content and as an object. The history of Judaism will be constantly characterized by this double simultaneous sacredness. According to the scholar literature, this phenomenon has been unique in the Mediterranean and Middle Eastern worlds ever since the end of Antiquity. At the time, two new book cultures were born almost simultaneously : that of emergent Christianity and that of Judaism in change. I think that drawing attention to this novelty 
will help us to one day explain this phenomenon, even if at present there is no hypothesis in relation to Judaism.

2 The rationalisation of this double sacredness in the rabbinical texts consists in the hermeneutical valorisation of material aspects. But, on the other hand, the hermeneutical enterprise makes use of procedures for the reification of writing; hence ensue a whole array of discussions on the form of letters and the meaning of that form. In that, we are witnessing a double phenomenon : the "textualisation" of reality and the "reification" of the text. ${ }^{2}$

3 This aspect can be observed and materializes itself on different levels. I will mention three levels of what I consider to be a case of textual reification: first comes the text of the Torah as a sacred object; the second level is the form of biblical exegesis represented by the midrash, a technique which explodes the usual unity of signification - the sentence or the word - in order to use the parts thus obtained as one would use a toolbox (see gematria, notarikon, the form of letters); the third level refers to the letter itself (see the ornaments pertaining to certain letters). Probably this categorisation is neither exhaustive nor pertinent enough but my interest is not that of developing it ; I only want to provide a larger scope than the Jewish religious imaginary for the examples which I will analyse in what follows.

\section{The Scroll}

4 Let us start by what I have called the first level of reification, which concerns the scroll, the book as an easily perceptible object. In fact, it is possible that the process of canonizing a text ran parallel to that of its sacralisation as an object. Nevertheless, by contrast, if the opinions on the "knowledge of the Torah" were frequently present in the writings of the Second Temple, the idea of "material conformity" and its binding rules only appear in the Mishna. The first indications of the ritual conformity of a Torah scroll can be found in the tractate Meguilla, especially in the commentaries of the Gemara. I will return to that. This tradition develops so extensively in later periods that the Talmud will include a minor tractate of the "Scribes", Massekhet Sopherim, dating back to the eighth century.

Undoubtedly getting their inspiration from the juridical sphere, Rabbis rationalize the idea of conformity by means of the injunction "not to add or subtract anything" (Eruvin 13a). The phrase finds support in the deuteronomical verse "You will keep and practice all I command without adding or subtracting anything" (Dt 13.1). Rabbis have always interpreted that verse in reference to a scribal activity. According to the rabbis, if we ignore that commandment we expose the entire Universe to the threat of extinction.

Yet scribes are aware that they make copies: their activity must be ritual but it is not a "liturgy". The idea of the copy is based on the different imaginary which governs the gift of the Law on Mount Sinai and their own activity: Moses had received the tables of stone ${ }^{3}$, so write the scribes on parchment or papyrus scrolls. The manner in which the rabbis imagine the episode of the Torah gift is highly enlightening as to the manner in which they view the relation between "the written" and the act of "writing".

7 We hereby notice that the stakes of "writing" are comparable to the stakes of the "written", of the content, a phenomenon which manifests itself in the controversies surrounding the original writing of the Tables of the Law. What this denotes is an idea of 
revelation in which the abstract and the material are inextricably related. Thus, the question of innovation focuses not only on the precepts of the Torah but also and primarily on the writing of this. Making not only a "program" but a revealed "graphic print" out of the Torah denotes a particular notion of "language as a faculty whereby humans express themselves [langage]" and of "language as a system of communication [langue]", as we will see later. Here we find ourselves within the clear problematics of sacred language.

In order to illustrate these ideas, I will rely on two passages, the Jerusalem Talmud tractate Meguilla and the eponymous Babylonian Talmud tractate. The two tractates speak of writing and of the language of Revelation in their own way.

\section{The Jerusalem Talmud: Meguilla 1.9}

How can one explain that Hebrew lost its sacred monopoly? - This is the question that worries Talmudic commentators. Indeed Gn 11.1 rightly says, "All the earth had one language and used the same words." According to Rabbi Eliezer, this meant that people spoke the seventy existing languages in full understanding of each other, whereas for Rabbi Yohanan this is a reference to "the language of the Unique of the world, the sacred language". The incongruity in relation to the Rabbis' contemporary situation is explained by Bar Kappara, when interpreting the following verse from Gn 9.27, "God is to extend Japhet's possessions, he is to live in Sem's tents" as meaning that "we will speak Japhet's language when in Sem's tent". Language thus ceases to be a marker of identity and the continuation of the Gemara develops a particular notion of the nationhood, one which does not connect nation with language but with writing. The consequence of this will be to give free hand to interpretation and to tighten the regulations of manufacturing.

The text continues with a functional division of languages which are not only supposed to explain but also to legitimate multilingualism. By doing that, the Hyerosolomitan Gemara undertakes a conceptual and lexical gliding between "language" and "writing" :

R. Jonathan de Bet-Gobrin says: There are four beautiful languages (lashon) which are adequate for usage in the world, namely: Greek (loaz) for songs, Latin (romi) for the gerav $^{4}$, Syrian (sursay) for elegies, Hebrew (ivri) for speaking (dibbur).

Others join the ashuri for writing. The ashuri possesses a type of writing but no language, whereas Hebrew possesses a language but no type of writing. They (the Jews) have chosen ashuri as writing and Hebrew as language. ["Why does this writing bear the name ashuri?" "Because it is substantial (meushar). According to R. Levi ${ }^{5}$, that label reminds one that it has been imported from Assyria (Ashur)."]

11 The word ashuri designates the square letters that were adopted after returning from the first Babylonian exile. This is the Aramaic alphabet which replaced the ancient so-called Paleo-Hebrew writing, the latter alphabet still subsisting in Samaritan writings to the present day. What is especially remarkable to note here is that ashuri was included in a series of "languages" (lashon). The collusion is partly due to the fact that Greek, Latin, Syrian and Hebrew are at times "languages" and at times "writings". Nevertheless, they don't share the sphere of the written but that of orality: song, talk, elegy, discourse. In order to make sounds visible, Jews "have chosen" signs that are not characteristic of their language: "Hebrew has no writing". Simultaneously, ashuri is not attached to a language ; it is free of such conditioning and paves the way to the rabbinic hermeneutics of letters. The meaning of its label-name is obscure for the rabbis and asks for exegesis: therefore, ashuri is linked to meushar (right, substantial) or to Ashur, Assyria. It is remarkable to note 
how one becomes aware of its "secondary" character in relation to Revelation and of the fact that it is a "borrowed" piece of writing. So ashuri is separated and hence, different from both language and time of Revelation. But if this is the case, the question of the Law writing on Mount Sinai gives rise to debates :

\section{First Opinion: the original writing of Mount Sinai Revelation was replaced by Esdras}

Baraitha $^{6}$ : We have taught that R. Yosse sais : Esdras would have deserved to have the Law given by his intermediary if Moses' generation had not outdone him. But if the Law was not given by his intermediary, he gave "writing" and "language" (ktav ve-lashon), as it is written: the writing is in Aramaic (katuv aramit) and is translated (meturgam) in Aramaic (Esd 4.7)7 so that they cannot read this writing (Dn 5.8). This proves that it has been replaced8.

This first opinion on the gift of "writing" once again relates it to "language". By contrast to preceding assertions about the ashuri, here, Rabbi Yosse clearly identifies it with Aramaic as "language and writing". The mediator of the "writing" is Esdras, the "second Moses" in rabbinic literature. Credit is generally given to Esdras for the invention of the targum, cantillation and exegesis. But if the word aramit at times designates "language" and "writing", this means that the Law was written in aramit, i.e. in square characters, and the translation, targum, was also in Aramaic. In order to discard any misunderstanding, a second verse is invoked for support: in Belshatzar's post-Revelation time, an epoch described by Daniel, "writing" wasn't understood. The impossibility to understand "writing" thus proves its novelty and the fact that it has been only recently received, in postexilic times, through Esdras mediation.

\section{Second opinion: Mount Sinai Revelation was given in intermingled writing}

R. Gamaliel ${ }^{9}$ says: The Law was promulgated in a piece of writing using intermingled letters (raats). The opinion conforms to that of R. Yosse.

Rabbi Gamaliel not only confirms the gift of Esdras' writing with square letters but also specifies that the original writing consisted of "intermingled" characters. We cannot know if the Rabbi's interpretation refers to what we call today Paleo-Hebrew writing but the evolution of the Revelation leaves room for understanding an interesting aspect of the rabbinical historical imaginary, the manner in which they conceived the ideas of evolution and progress.

\section{Third opinion : Mount Sinai Revelation was given in ashuri}

According to Rabbi ${ }^{10}$, it was delivered in ashuri writing; when Israel sinned, the writing got converted in intermingled characters and when it later became virtuous again, under Esdras, the characters also became ashuri once again. As it is said:

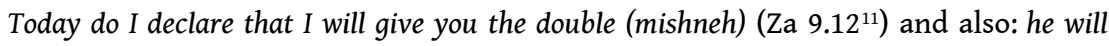
write him a double (mishneh) of that Law on a book (Dt 17.18) ${ }^{12}$; this is an allusion to a form of writing prone to changes.

The third opinion belonging to the Rabbi connects the gift of writing to the general scheme of Jewish history : sin and expiation of sins. In this case, Esdras is no longer the civilizing hero but only the réparateur. He does not receive the Writing/Scripture per se 
but "a double". Rabbi, the one to whom this thesis is attributed, interprets the word mishneh, "double", not as an identical copy but as a "second" revelation. And as it is inconceivable to receive a "new" Law, the only possible change is related to "writing". So Rabbi does not accept to make Esdras the mediator of "canonical" writing, ashuri; this attitude obliges him to force his biblical proof texts by introducing an understatement in the interpretation he gives to the word mishneh, "double, second". He chooses to consider the "second" not as being "identical" but as being "modifiable" and as "modified". The material aspects are sufficiently important to represent the object of a punishment that would equate to a form of divine silence : writing becomes "intermingled". Meanwhile, writing with square letters, a precious good, is removed from the Jewish people up to the time of Esdras.

After exposing these three possibilities, the Talmudic passage develops its arguments in one way or another. Thus, the Rabbi's opinion finds support in a Tannaitic dictum (a Baraitha) :

It was taught that Rabbi Simon ben Eliezer ${ }^{13}$ says in the name of R. Eliezer ben Parta and this one in the name of R. Eliezer ben Modai: the Law must have been written in ashuri characters. What is the proof? The vav-s [are] columns (amudim) (Ex 27.1014); thus the vav-s in the Law must be straight as a column (amud).

Since the letter "vav" in ashuri square script ressembles a column, it means that the script could not have been intermingled (raatz) characters. The shape of the letters becomes an argument in point of reconstituting the history of the Revelation. In any case, the miracle is necessary:

Rabbi Levi said: According to those for whom the Law was given in intermingled characters, one is to deduct that the ayn held by miracle: and according to those who sustain that the Law was given in ashuri characters, one is to deduct that the samekh equally held by a similar miracle. Rabbi Jeremiah ${ }^{15}$, in the name of Rabbi Hyya bar $\mathrm{Ba}^{16}$ and of Rabbi Simon Terihon, says: in the original Torah there was no he nor any closed mem but only a closed samekh. ${ }^{17}$

In the rabbinic imaginary the Tables of the Law are so inscribed that they can be read both ways. If the signs are not universally visible it is because they are not drawn but they are carved. Such letters as the intermingled ayn or the ashuri samekh come up to the circumference of a circle without being attached to the mass of the Table. It is the reification of a vacuum, even the abstraction of a form. Only a miracle can explain their subsistence on the Tables of Law.

The role of the miracle for the material consistence of the Torah is developed in the Babylonian tractate Meguilla, in a later passage from the fourth century. If previously the connection between form and content was operated by means of the bias of language, in this case the connection is operated by means of analysing the principle of innovation ( hidush).

\section{Babylonian Talmud : Meguilla 2b-3a}

Rabbi Jeremiah (or, according to others, Rabbi Hyya ben Abba) said : The final forms of letters mem, nun, tsadek, peh, kaph, had been "told" by the watchmen.

Is what you believe right? Isn't it written These are the commandments (Lv 27.34), which implies that no prophet is authorized to introduce anything new? Moreover, Rabbi Hisda ${ }^{18}$ added that: the mem and the samekh have guarded their place on the Tables of the Law by miracle ${ }^{19}$. 
Here is how it happened: (These letters) were in use but the people didn't know what form to put in the middle of the word and what form to place at the end of the word; thus, the Watchmen established that open forms will be used in the middle and closed forms at the end. Yet, after all was said and done, one thing was left, the text that These are the commandments, implying that no prophet had the right to introduce anything new afterwards. We must then understand that the letters had been forgotten and the Watchmen restored them. Moses versus Esdras, but the basis of consensus is the gift of the Torah on Mount Sinai which was written in square letters. Yet the controversy is centred on the open and closed form of certain letters. Rabbi Jeremiah attributes them to the Watchmen, a term used to designate the prophets that succeeded Moses. Introducing something new, be it only on the level of form, nevertheless equates to transgressing the Deuteronomic verse at the end of the Revelation. The Watchmen's role thus needs to be delimited more clearly : in a first variant, they only put order in the use of form without creating that form themselves; in a second variant, they restored the previously forgotten forms. Rabbis usually solve the tension between the novelty and closure of the Revelation by the bias of the anamnesis. This is also the case of Targum, the Aramaic version of the Bible, to give one example, which was also "forgotten and restored" (Meguilla 3a). The same artifice of restoring the forgotten is part of the Christian thematics of the Adamic language to which Maurice Olender has dedicated some of his studies ${ }^{20}$.

It should also be noted that the completion of the Tables of the Law finds expression in the phrase "all was said and done": word and gesture, abstraction and materiality conjoin together to make the Law. Both are subject to canonicity and they are hermeneutic aims.

\section{Practical Rules}

21 Having highlighted the etiological imaginary of writing and its implications on the definition of a textual community, let us go on to examine the normative imaginary related to the writing of the Torah scrolls. I talk voluntarily of imaginary since, as Judith Schlanger has proved it in her intervention on "La mise en texte: écriture, pensée, lecture" ${ }^{21}$, there is no genuine kosher scroll. The enquiry over texts can't establish the degree of applicability for the norms, nor can it establish if they can be applied selectively or what are the means to go round the norms, or what are the agreed limits allowing for scribal transgression.

As I have already specified in the introduction, the commandments (mitzvot) related to the fabrication of scrolls are codified in the tractate Meguilla as well as in a subsequent post-Talmudic tractate, Sopherim. Without making the claim for an exhaustive and systematic analysis of these instructions, I will only enumerate some prescriptions that invite one to reflection in relation to the topic chosen for the present debate and having to do with what I have called "the reification" of the text and the letter.

\section{Requisites for Sacredness}

Let us start with the fundamental passage of Mishna Meguilla in which the confusion between "language" and "writing" leaves room for a long discussion bearing on the prohibitions related to translation and the prohibitions related to transliteration:

Cahiers « Mondes anciens », 1 | 2010 
Mishna : There is no difference between books [of the Bible] and tefillin and mezuzah save that the books [of the Bible] may be written in any language (kol lashon) while tefillin and mezuzah can only be written in ashuri. Rabban Simeon ben Gamaliel says : "For the books [of the Bible] we haven't authorized any other language, with the exception of Greek." (Meguilla 8b)

To that the Babylonian Gemara opposes a Tannaitic tradition (Baraitha) which implies a contradiction with the Mishna :

[A Scriptural scroll containing] a Hebrew text written in targum (Aramaic) or an Aramaic text written in Hebrew, or [either] in Hebraic script does not defile the hands; [it does not do so] until it is written in ashuri script upon a scroll and in ink'! (Meguilla 8b)

This permanent to and from movement between signifier and signified, between form and content, is far from illuminating the meaning; on the contrary, it makes it more and more ambiguous. How is one to understand the phrase katuv be-aramit? Katuv can designate the Scripture as well as something "written". Similarly, the word aramit can designate either the square alphabet or the Aramaic language, hence another confusion, that between Aramaic texts of the Bible and the targum, the Aramaic translation of the Bible. The rabbis of the Talmud try to solve this total imbroglio, especially since it is the case of a ritual context, that of making manuscripts that are ritually appropriate.

\section{The Concern over Formal Clarity}

The fear of "non-distinction", of non-identity of the "mixed letter", is another topos underlying the conditions of sacredness. We cannot write a letter as another: the alef as an ayn, a beth as a kaf, a kaf as a beth, a gimmel as a tsaddek and tsaddek as gimmel, a daleth as a resh and a resh as a daleth, a he as a heth and a heth as a he, a vav as a yod and a yod as a vav, a zayin as a nun and a nun as a zayin, a teth as a peh and a peh as a teth, a mem as a samekh and a samekh as a mem, the closed letters as open letters and the open letters as closed ones (Shabbat 103b).

At the same time, each letter has to be surrounded by parchment as there shouldn't be any overlapping. Here we find the imaginary of the Tables of the Law and of writing with intermingled letters corresponding to the sin of Israel.

The text is never completely interdependent on the idea of support. The letter is very material in its graphic trajectory while it is also an abstract entity which does not make one body with the parchment. In what regards this topic, here is an example of Talmudic questioning: can we use the blank space between blocks of writing? The debate is part of the Babylonian Talmud Shabbat 116a:

But why so conclude [that we must save it] on account of its blank space? As for the place of the writing, I have no doubt, for when it was sanctified it was on account of the writing, [and] when its writing goes its sanctity goes [too]. My problem is only in respect of [the blank spaces] above and below, between the sections, between the columns, [and] at the beginning and the end of the Scroll. Yet conclude [that it must be saved] on that account? It may mean [there] that one had cut off [the blank spaces] and thrown them away. 


\section{The Embellishment of Letters}

\section{R} nun, zayin, gimmel, and tzaddeh. These ornaments will be integrated in the tradition and will form the focus of rabbinic discussions throughout the entire history of Judaism. The tradition also reports a book entitled Sefer ha-tagin ${ }^{23}$. The picture below, not reproducing a biblical manuscript from the Talmudic epoch since we don't possess one, is meant to give an image of the manner in which tradition has used those tagin and ketarim.

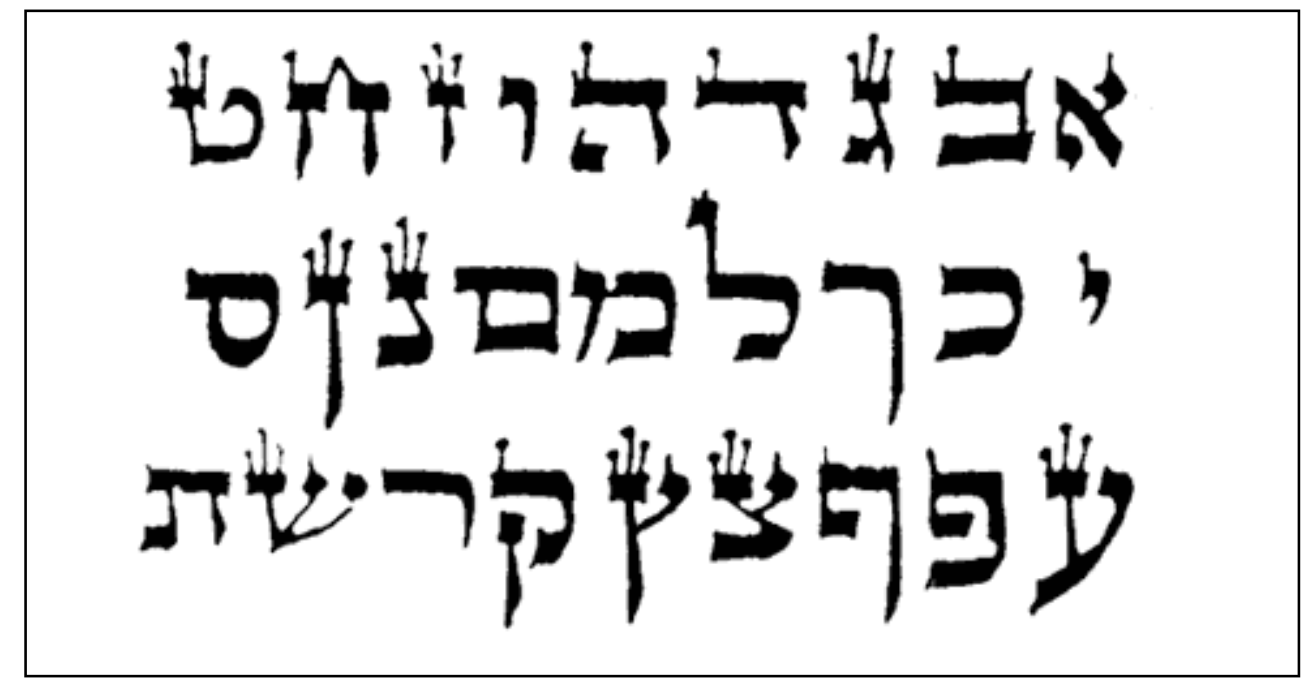

How does the Talmud reason over the importance of ornaments? The following aetiology can be found in Menahot 29b:

Rav Juda says in Rav's name: "When Moses climbed high up, he found the Unique One, May He Be Blessed, who was in the process of placing wreathes on the letters." Moses: "Master of the Universe, who holds up Your hand?" He answered: "Many generations from now, there will be a man named Akiba ben Joseph who will interpret each wreath of the Law's letters." "Master of the Universe, let me see him." "Turn around !" Moses went eight steps down and listened to the discussions about the Law. Not being able to understand them, he felt uncomfortable. But when they reached a certain topic and the disciples asked, "How come you know that?" and the other's response was "It was given to Moses on Mount Sinai", he felt better. Then, he turned back toward God: "Master of the Universe, You have such a man and you give the Torah through me?" And God answered: "Be silent. This is my decision."

Rab Judah said in the name of Rab: "When Moses ascended on high he found the Holy One, blessed be $\mathrm{He}$, engaged in affixing coronets to the letters. Said Moses : 'Lord of the Universe, Who stays Thy hand ?' He answered : 'There will arise a man, at the end of many generations, Akiba b. Joseph by name, who will expound upon each tittle heaps and heaps of laws'. 'Lord of the Universe', said Moses, 'permit me to see him'. He replied, 'Turn thee round'. Moses went and sat down behind eight rows [and listened to the discourses upon the law]. Not being able to follow their arguments he was ill at ease, but when they came to a certain subject and the 
disciples said to the master 'Whence do you know it ?' and the latter replied 'It is a law given unto Moses at Sinai' he was comforted. Thereupon he returned to the Holy One, blessed be He, and said, 'Lord of the Universe, Thou hast such a man and Thou givest the Torah by me !' He replied, 'Be silent, for such is My decree'. article, "Le Tout, l'Énigme et l'Illusion ", published in Le Débat in 1990, she examines the anthropological scope of three types of writing: the graphical "whole" of the wedgeshaped, the enigma of the Hebrew consonantal alphabet, and the illusion of the entirely 
decontextualised Greek alphabet. The author says that "the various writings don't establish the same type of graphic connection between the things of language and the things of the world. [...] This happens because every piece of writing establishes a certain relationship between its user and the world ; by telling the world in the written the user invades, explores and at times transforms the intrinsic possibilities of his graphic print." that focus on writing. to me always pertinent. that focus on writing.

of the three graphic strategies analysed in the article, that of the Persian Empire is the most relevant one for our interest here. Certainly, the interpretation given to the graphic strategy of the Hebrew people, for whom writing is an integral part of the revelation and each written word a consonantal enigma whose sense is clarified only in context, seems

Yet, the solution found by the Achemenid Persians in what regards imperial multilingualism sheds light on the portfolio we have presented here. It is in Achemenid Persian that we find the most significant development of trilingual royal inscriptions, the Great King having the super-human power of multilingualism. "In the chain of the written necessary for the empire, the Persian language has functioned as a game of hideand-seek, under several linguistic-graphic masks." The consequence : "The graphic Whole characterising the wedge-shaped world has imploded: there was no longer a union between the written, language and the world, but language became autonomous in and through the indifferentiation of language; from now on, language belongs to the Interpreter who achieves it beyond languages and writings." "The indifference of language which tells the world to the language which makes it, the indifferences of men to the language they write in order to say the world. » (Herrenschmidt 1990, p. 107)

Jewish bilingualism and multilingualism finally raise similar questions, while at the same time pointing to the unprecedented importance given to graphic signs.

Just as the Persian king is the guarantor of truth beyond languages, the Torah is the word of truth beyond its linguistic particularism.

Finally, it might be that for the rabbis this is an instance of securing a counterbalance to the other grand theme of their ideology : orality. The authority of the Rabbi's / Torah interpreter's oral statement is counterbalanced by the uniformity of writing.

The texts constituting the Jewish tradition deserve being rethought in light of studies

\section{BIBLIOGRAPHIE}

BLANK Debra Reed, 1995, «It's time to take another look at our "little sister" Soferim : a

bibliographical essay ", Conservative Judaism, 48/1, p. 10.

BRIANT Pierre, Histoire de l'Empire perse. De Cyrus à Alexandre, Paris, 1996, p. 535-536.

HERRENSCHMIDT Clarisse, 1990, « Le Tout, l'Énigme et l'Illusion. Une interprétation de l'histoire de

l'écriture ", Le Débat, 62, p. 95-118. 
HEIDE Albert van der, 2006, " "Mem and samekh" stood by a miracle : the sugya on the Hebrew script (Shabbat 103a-104a)», Studia Rosenthaliana 38-39, p. 137-143.

HERRENSCHMIDT Clarisse, 1996, « L'écriture entre mondes visible et invisible », in J. Bottéro, Cl. Herrenschmidt, J.-P. Vernant (éds), L'Orient Ancien et Nous. L'écriture, la raison, les dieux, Paris, p. 95-188.

LEVY-RUBIN Milka, 1998, " The language of Creation or the primordial language: a case of cultural polemics in antiquity ", Journal of Jewish Studies, 49/2, p. 306-333.

MACDONALD M. C. A., 2006, «Literacy in an Oral Environment », in P. Bienkowski, Ch. Mee, E. Slater (éds), Writing and Ancient Near Eastern Society. Papers in Honour of Alan R. Millard, New York, p. 49-118.

OLENDER Maurice, 1989, Les langues du paradis. Aryens et Sémites : un couple providentie,Paris. OLENDER Maurice, 1993, « Europe, or how to escape Babel », in A. Grafton et S.L. Marchand (éds), Proof and persuasion, Wesleyan U. P.

RоOт M., 1997, « Cultural Pluralisms and the Persepolis Fortification Tablets », Topoi Suppl. 1, p. 229-252.

schWARTZ Seth, 2005, « Language, power and identity in ancient Palestine », in C. Bakhos (éd.), Ancient Judaism in Its Hellenistic Context, Leiden, p. 52-84.

SIRAT Colette, 1991, « Les rouleaux bibliques de Qumrân au Moyen Âge : du Livre au Sefer Tora, de l'oreille à l'œil », Académie des Inscriptions et Belles-Lettres : Comptes Rendus (avril-juin 1991), p. 415-432.

SIRAT Colette, 1997, " Orality/literacy, language and alphabets: examples of the Jewish people », in Clotilde Pontecorvo (éd.), Writing Development; an Interdisciplinary View, Amsterdam, Philadelphia, p. 101-115.

SIRAT Colette, 1998, «Les lettres hébraïques, leur existence idéale et matérielle ", in A. L. Ivry, E. R. Wolfson, A. Arkush (éds), Perspectives on Jewish Thought and Mysticism; Dedicated to the Memory of Alexander Altmann, Amsterdam, p. 237-256.

TARAGin Moshe (Rav), « The Crowns of the Hebrew Script », in Talmudic Methodology, Yeshivat Har Etzion - Israel Koschnitzky Virtual Beit Midrash, http://www.vbm-torah.org/archive/ metho60/05taggin.doc.

VELTRI Giuseppe, 2002, « Tradent und Traditum im antiken Judentum », in Id., Gegenwart der Tradition, Leiden, p. 3-27.

\section{NOTES}

1. My special thanks are addressed to Dana Mihailescu from the University of Bucharest, who provided the English version of this paper.

2. Colette Sirat describes the process as follows: "The Sefer Torah has become the Sanctuary where God resides. Henceforth, the divine word gets embodied in the visible letters, it is no longer just miqra, what the ear can hear, but also and in particular what the eye can grasp. [...] The idea that the Torah is made up of letters, not of sounds, runs throughout the entire history of Jewish thought." (Sirat 1991, p. 432, my translation)

3. See Shabbat $104 a$, Sheqalim $6,49 b$. 
4. Word difficult to understand in this context; the proper meaning is "battle". Translations render usually by "dispute".

5. Can this be the disciple of Resh Laqish who lived in the third century?

6. Following rabbinical attributions, this is a Baraitha dating back to the second century.

7. Here is the verse in context: "And in the time of Artaxerxes, Bischlam, Mithredath, Thabeel, and the rest of their colleagues wrote to Artaxerxes, king of Persia. The letter was transcribed in Aramaic characters and translated in Aramaic (katuv aramit u-meturgam aramit)."

8. "All the king's sages entered, but they couldn't read the writing and explain its meaning to the king."

9. Probably Galamiel II, at the end of the first and the beginning of the second century.

10. Rabbi Juda the Prince, second and third centuries.

11. "Go back to the fortress, captives full of hope! I declare it today once again; I will give you the double (mishneh ashiv lekha)".

12. "When he climbs to the royal throne, he will have to write a copy of that Law on a scroll for his usage and under dictation from the Levite priests (ve-ktav lo et-mishneh ha-torah ha-zot al sefer )."

13. A colleague of Rabbi. But the Baraitha dates back the chain of transmission up to Eliezer ben Modai, dead in 134.

14. The literal sense of the verse is the following: "The hooks of columns (vavei ha-amudim)".

15. A Palestinian Rabbi from the fourth century, born in Babylonia and subsequently the chief of the Academy of Tiberias.

16. Active at the end of the third century (cca 270-300).

17. Because their form is similar to a closed circle.

18. A Babylonian Rabbi at the end of the third and the beginning of the fourth century.

19. Because their form is similar to a closed circle.

20. Olender 1989.

21. The lecture was delivered during the Study Days organized by Christian Jacob within this GDRI convention, entitled « Les mondes lettrés ", and held on October 13-14, 2006.

22. This comes from the letter zayin, a letter to which resemble the three decoration lines that form a set, a taga or a keter, "wreath". Zyun is also translated by "armour".

23. Copied by Simha ben Samuel, Rachi's disciple, in his Mahzor Vitry. An adnotated edition was made by Senior Sachs in 1866 .

24. Subsequent commentators haven't reached any consensus in this regard: some of them will argue in favour of essential elements, others won't. Among the reasons that have been invoked is that of ensuring the "square" character of these letters and that of avoiding their round character.

\section{RÉSUMÉS}

Comme l'affirme l'argumentaire de la journée d'étude sur «Écritures rituelles », l'écriture est généralement associée à l'oralité et étudiée à la lumière de la coupure cognitive énoncée et théorisée par Jack Goody, théorie qui a donné naissance au domaine des «literacy studies". L'approche choisie est de mettre face à face non pas «écrit » et «oral » mais «écriture » et « rituel». Dans le judaïsme le «faire» n'a jamais été absent, ni de la religion, ni de 
l'historiographie : il n'est pas question ici de réhabiliter cette notion dans le judaïsme. Par contre, ce qui me semble intéressant est d'interroger les rapports entre "écrit », "écriture » et « rituel ». Je reprends ici la distinction faite par les concepteurs du programme, entre « écrit » et " écriture ", où cette dernière et entendue comme "le tracé même saisi dans son exécution au cours d'une opération rituelle ». Autrement dit, la notion de "rituel » est entendue comme déjà incluse dans celle d' «écriture » et la tension fertile pour l'étude est celle entre le «contenu » et la « forme », ou entre « le sens de ce qui est écrit » et les aspects matériels qui le conditionnent. Nous essayons ainsi de répondre à la question lancée dans le même argumentaire: "les conditions pragmatiques dans lesquelles s'élabore l'autorité de l'écriture ». Dans le judaïsme cette autorité est double : celle de l'« écrit » et, à partir d'un certain moment dans l'histoire, celle de l'« écriture ». À partir du Second Temple, la Torah est sacrée à la fois comme "parole » et comme « rouleau », à la fois de par son contenu et en tant qu'objet. L'histoire du judaïsme sera constamment traversée par cette double sacralité simultanée. Selon la littérature de spécialité, ce phénomène est unique dans le monde méditerranéen et moyen-oriental de la fin de l'Antiquité. À cette époque, à peu près simultanément, deux nouvelles cultures du livre voient le jour : celle du christianisme naissant et celle du judaïsme en mutation. Je crois que le fait de souligner cette nouveauté nous aidera un jour à expliquer ce phénomène, même si pour l'heure en ce qui concerne le judaïsme il n'existe aucune hypothèse. La rationalisation, à travers les textes rabbiniques, de cette double sacralité consiste en une mise en valeur herméneutique des aspects matériels. Mais d'autre part, l'entreprise herméneutique fait appel à des procédés de réification de l'écriture, d'où un ensemble de discussions sur la forme des lettres et la signification de cette forme. Nous assistons ainsi à un double phénomène : celui de la «textualisation » de la réalité et celui de « réification » du texte. Cet aspect est observable à plusieurs niveaux et se concrétise sur plusieurs plans. Je vais mentionner trois de ces niveaux de ce que je considère être une réification du texte : le premier est le texte de la Torah comme objet sacré ; le deuxième est la forme d'exégèse biblique qui est le midrach, technique qui fait exploser l'unité de sens habituelle qui est la phrase ou le mot, pour en utiliser les parties ainsi obtenues comme une boîte à outils (cf. gematria, notarikon, la forme des lettres) ; le troisième niveau concerne la lettre même (cf. les ornements afférents à certaines lettres). Cette catégorisation n'est probablement ni exhaustive, ni suffisamment pertinente mais mon propos n'est pas de la développer ici ; je voulais simplement situer les exemples que je vais analyser par la suite dans un contexte plus large de l'imaginaire religieux juif.

My attempt is to answer the question of "the pragmatic contexts within which the authority of writing is established". This authority is double in the case of Judaism as what is "written" and, starting with a particular moment in history, as the act of "writing". Starting with the Second Temple, the Torah is sacred as "word" and "scroll" at the same time as it is sacred by means of its content and as an object. The history of Judaism will be constantly characterized by this double simultaneous sacredness. According to the scholar literature, this phenomenon has been unique in the Mediterranean and Middle Eastern worlds ever since the end of Antiquity. At the time, two new book cultures were born almost simultaneously: that of emergent Christianity and that of Judaism in change. I think that drawing attention to this novelty will help us to one day explain this phenomenon, even if at present there is no hypothesis in relation to Judaism. The rationalisation of this double sacredness in the rabbinical texts consists in the hermeneutical valorisation of material aspects. But, on the other hand, the hermeneutical enterprise makes use of procedures for the reification of writing; hence ensue a whole array of discussions on the form of letters and the meaning of that form. We are witnessing there a double phenomenon: the "textualisation" of reality and the "reification" of the text. 
INDEX

Keywords : rabbinic hermeneutics, rabbinic script, rabbinic scripture, script and word reification

\section{AUTEUR}

MADALINA VÂRTEJANU-JOUBERT

Centre d'Etudes Juives, EHESS Paris et Centre Gustave-Glotz 